\title{
Brachytherapy in non melanoma skin cancer of eyelid: a systematic review
}

\author{
Rezarta Frakulli, MD!, Andrea Galuppi, MD!, Silvia Cammelli, MD!, Gabriella Macchia, MD², Simona Cima, MD³, \\ Maria A. Gambacorta, MD4, Ines Cafaro, MD55, Luca Tagliaferri, MD4, Elisabetta Perrucci, MD6․, Milly Buwenge, MD', \\ Giovanni Frezza, MD. Vincenzo Valentini, MD4, Alessio G. Morganti, MD' \\ IRadiation Oncology Center, Department of Experimental, Diagnostic and Specialty Medicine - DIMES, University of Bologna, \\ S. Orsola-Mal pighi Hospital, Bologna, Italy, ²Radiation Oncology Unit, Research and Care Foundation 'Giovanni Paolo II', Catholic University \\ of Sacred Heart, Campobasso, Italy, ${ }^{3}$ Radiation Oncology Unit, Oncology Institute of Southern Switzerland, Bellinzona, Switzerland, \\ ${ }^{4}$ Department of Radiation Oncology, Catholic University of the Sacred Heart, Rome, Italy, ${ }^{5}$ Department of Radiation Oncology, Istituti \\ Ospitalieri, Cremona, Italy, 'Radiation Oncology Section, Santa Maria della Misericordia Hospital, Perugia, Italy, ${ }^{7}$ Radiation Oncology Unit, \\ Bellaria Hospital, Bologna, Italy
}

\begin{abstract}
Purpose: Non melanoma skin cancers (NMSC) of eyelid are uncommon. Many treatments approach are available with surgery being considered as the gold standard. Radiotherapy is an effective alternative in patients unfit for surgery. Brachytherapy (BT) might be a better therapeutic option due high radiation dose concentration to the tumor and rapid dose fall-off resulting in normal tissues sparing. The aim of this review is to evaluate local control, toxicity, and functional cosmetic outcome of BT in NMSC of eyelid.

Material and methods: A systematic search of the bibliographic databases PubMed, Scopus, and Cochrane Library from the earliest possible date through October 2015 was performed. Only studies published in English were included.

Results: Six articles fulfilled the selection criteria and were included in our review. Due to high risk of bias, all studies were classified to provide a low level of evidence (according to Scottish Intercollegiate Guidelines Network Classification). No randomized controlled trials or case control studies were founded. Brachytherapy was well tolerated with acceptable toxicity and high local control rates (median: 95.2\%). Functional and cosmetic outcome were reported in five study as acceptable good functional-cosmetic outcome (median: 100\%).

Conclusions: To date, few evidences are available on the role of BT in eyelid NMSC, and they show satisfactory results in terms of local control and functional cosmetic outcome. Therefore, prospective controlled trials are justified.

J Contemp Brachytherapy 2015; 7, 6: 497-502 DOI: $10.5114 / \mathrm{jcb} .2015 .56465$
\end{abstract}

Key words: brachytherapy, eyelid, non melanoma skin cancer, systematic review.

\section{Purpose}

Eyelid tumors are uncommon and represent $5-10 \%$ of all skin cancers. Basal cell carcinoma (BCC) is the most common histological type representing $90 \%$ of all cases followed by squamous cell carcinoma (SCC), and less frequently by sebaceous cell carcinoma (SbCC), Merkel cell tumor and melanoma [1]. The most common localization are the lower eyelid (50-60\%) and medial canthus (25-30\%). Basal cell carcinoma are slow growing tumors with a metastatic rate ranging from 0.003 to $0.5 \%$ but they can be locally invasive infiltrating the lid margin or the lachrymal glands producing functional disability $[2,3]$. Squamous cell carcinoma are more aggressive than BCC: about $5 \%$ are metastatic and in these patients 5-year survival rate is only $25-40 \%$ [4].

Many treatment approaches are available: surgery, radiotherapy, cryotherapy, curettage, electrodissection, pho- todynamic therapy, and laser ablation [5]. Surgery is considered the gold standard therapy, and the treatment aims are definitive tumor control and preservation of the functional structures $[6,7,8]$. Radiotherapy is also a good alternative if preservation of functional structures is not possible with surgery. Brachytherapy (BT) might be a better therapeutic option due to intrinsic advantages, including high radiation dose concentration into the tumor and rapid dose fall-off at target periphery with optimal sparing of normal tissues in these sensitive structures in shorter treatment time.

Despite the potential interest about the BT in the treatment of these tumors, randomized controlled trials, systematic reviews and/or metanalyses are lacking in literature. Therefore, the aim of this review was to systematically evaluate the available literature on local control and functional cosmetic outcome after BT of non melanoma skin cancer (NMSC) of eyelids. 


\section{Material and methods}

A systematic search strategy of the bibliographic databases PubMed, Scopus, and Cochrane library from the earliest possible date through October 13, 2015 was performed $[9,10,11]$. The search strategy was based on the following terms: ("eyelid neoplasms"[MeSH Terms] OR ("eyelid"[All Fields] AND "neoplasms"[All Fields]) OR "eyelid neoplasms"[All Fields] OR ("eyelid"[All Fields] AND "cancer"[All Fields]) OR "eyelid cancer" [All Fields]) AND ("brachytherapy"[MeSH Terms] OR "brachytherapy"[All Fields]). To avoid missing relevant studies we chose this strategy with high sensitivity but low specificity.

\section{Criteria for considering studies to be included in this review}

Type of studies: we included human studies of any design (randomized, prospective, retrospective studies) and case series with exception of case reports. Only studies published in English were included in this reviews. Types of participants: studies reporting on patients with a diagnosis of non melanoma skin cancer of eyelid based on histological evaluation were included. Type of interventions: eligible intervention included BT in NMSC of eyelid independently of technique, dose, dose rate, and treatment setting (curative or adjuvant).

Type of outcome measures: the primary outcome was local tumor control after BT. The secondary outcomes were acute - late toxicity and functional cosmetic results independently of used scales.

\section{Study selection and quality assessment}

Two independent authors (RF, GM) screened citations at the abstract level to identify potentially relevant

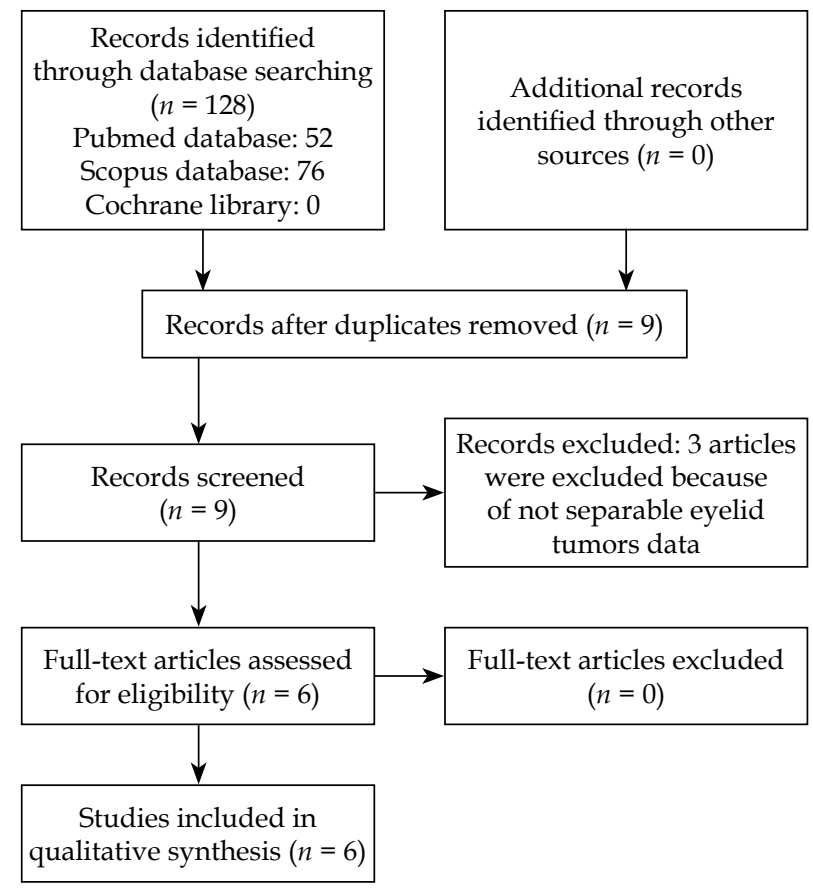

Fig. 1. Flow chart of systematic search and review process studies and case series. Potentially eligible citations were retrieved for full-text review, with disagreements resolved by a third author (AGM). We obtained the following information from each report: author identification, year of publication, medical center, study design characteristics, study population, BT technique, delivered dose, total treatment time, local control, toxicity, and functional cosmetic outcome. In the studies where overall treatment time was not reported it was calculated based on dose rate and total dose. Scottish Intercollegiate Guidelines Network (SIGN) criteria was used to classify the quality of evidence [12].

\section{Results}

Through a process of screening the title and the abstract, 9 articles were identified $[13,14,15,16,17,18,19,20$, 21]. The flowchart of systematic literature search process is shown in Figure 1. After full text, review of 3 articles on skin cancer BT were excluded because eyelid tumors data were not reported separately $[16,17,18]$. Therefore, 6 articles fulfilled the inclusion criteria and were included in our review. The characteristics of these studies included in the review are summarized in Table $1[13,14,15,19$, $20,21]$. No randomized controlled trials or case control studies were founded. Of the selected studies, 1 was prospective [14] while the others were retrospective reports $[13,15,19,20,21]$. Because of high risk of confusion or bias, all studies were classified to provide a level of evidence graded as 3 according to SIGN classification [12]. Table 2 shows a summary of the recorded outcomes.

\section{Treatment characteristics and local control}

In all studies, interstitial BT with ${ }^{192}$ Ir source was the used technique. Both low-dose-rate (LDR) in 3 studies $[13,14,19]$ and high-dose-rate (HDR) in the other 3 studies $[15,20,21]$ were used. The overall treatment time did not exceed 1 week $[13,14,15,19,20,21]$. In the LDR group, 249 NMSC of eyelids were included. Different dose rates and delivered dose were used. Delay et al. reported the results of the largest series with 160 patients and 165 eyelid tumors. Biopsy was performed in 131 lesions and the results were: $85 \%$ BCC, $14.5 \%$ SCC, and $0.5 \%$ adenocarcinoma. One hundred fourteen lesions were not previously treated and 51 lesions were local recurrences. Tumor size was $<2 \mathrm{~cm}$ in $79.5 \%$ of cases, and $2-5 \mathrm{~cm}$ in $20 \%$. According to histotype, the delivered dose was $60 \mathrm{~Gy}$ for BCC and 70 Gy for SCC, with a dose rate ranging from 65 to $90 \mathrm{cGy} / \mathrm{h}$. Six years failure rate was $2.6 \%$ in primary lesions and $5.9 \%$ in recurrent tumors. Overall local control was $96.4 \%$ [13].

Krengli et al. reported the results of 60 patients, 51 patients with primary unresected carcinoma, 5 patients with local recurrence, and 4 patients treated with postoperative BT. The tumor size was $<3.5 \mathrm{~cm}$. Mean delivered dose was $65 \mathrm{~Gy}$ (range 51-70 Gy) with dose rate ranging from 50 to $60 \mathrm{cGy} / \mathrm{h}$ [19]. With a mean follow-up of 92 months, local failure rate was $3.3 \%$ in previously untreated lesions (2 patients with T2 carcinoma) [19]. Conill et al. reported the results of 24 tumors involving the eyelid tarsal structure 
Table 1. Summary of studies where brachytherapy was used in non melanoma skin cancer of eyelid

\begin{tabular}{|c|c|c|c|c|c|c|c|c|}
\hline $\begin{array}{l}\text { Authors } \\
\text { (reference) }\end{array}$ & $\begin{array}{l}\text { Medical } \\
\text { center }\end{array}$ & $\begin{array}{l}\text { Study } \\
\text { design/ } \\
\text { Setting }\end{array}$ & $\begin{array}{l}\text { No. lesions/ } \\
\text { patients } \\
\text { (\% previous } \\
\text { surgery) }\end{array}$ & $\begin{array}{c}\text { Tumor } \\
\text { characteristic }\end{array}$ & $\begin{array}{l}\text { Treatment } \\
\text { character- } \\
\text { istic }\end{array}$ & Eye shield & $\begin{array}{l}\text { Dosage } \\
\text { Gy/Fraction } \\
\text { (treatment } \\
\text { intent) }\end{array}$ & $\begin{array}{l}\text { Treatment } \\
\text { delivered } \\
\text { time }\end{array}$ \\
\hline $\begin{array}{l}\text { Daly } \\
\text { et al. [13] }\end{array}$ & $\begin{array}{l}\text { Centre Clau- } \\
\text { dius Regaud, } \\
\text { Toulouse, } \\
\text { France }\end{array}$ & $\begin{array}{l}\text { Retrospec- } \\
\text { tive/Curative }\end{array}$ & $\begin{array}{l}165 / 160 \\
(30.9 \%)\end{array}$ & $\begin{array}{c}\text { BCC: } 85 \%, \\
\text { SCC: } 14.5 \% \\
\text { Adenocarcino- } \\
\text { ma: } 0.5 \% \\
\text { T } \leq 5 \mathrm{~cm}: 95 \% \\
(\mathrm{~T} \leq 2 \mathrm{~cm} \\
>79.5 \%)\end{array}$ & $\begin{array}{l}\text { Interstitial } \\
\text { LDR } \\
\text { Dose rate: } \\
65-90 \text { cGy/h }\end{array}$ & No & $\begin{array}{c}60(\mathrm{BCC}) / \\
1 \text { (curative) } \\
70(\mathrm{SCC}) / \\
1 \text { (curative) }\end{array}$ & 3-4 days \\
\hline $\begin{array}{l}\text { Conill } \\
\text { et al. [14] }\end{array}$ & $\begin{array}{c}\text { University } \\
\text { of Barcelona } \\
\text { Hospital } \\
\text { Clinic, Spain }\end{array}$ & $\begin{array}{c}\text { Prospective/ } \\
\text { Curative* }^{*}\end{array}$ & 24/23 (0\%) & $\begin{array}{c}\text { BCC: } 79.2 \%, \\
\text { SCC: } 26.7 \% \\
\text { Adenocarcino- } \\
\text { ma: } 4.2 \% \\
\text { Mean } T \approx 1.3 \mathrm{~cm}\end{array}$ & $\begin{array}{c}\text { Curettage + } \\
\text { interstitial } \\
\text { LDR } \\
\text { Mean dose } \\
\text { rate: } \\
73 \text { cGy/h }\end{array}$ & No & $\begin{array}{c}40 / 1 \\
\text { (curative) }\end{array}$ & 2-4 days \\
\hline $\begin{array}{l}\text { Azad } \\
\text { et al. [15] }\end{array}$ & $\begin{array}{c}\text { Regional } \\
\text { Cancer } \\
\text { Centre, } \\
\text { Dr. B. R. A. M. } \\
\text { Hospital, } \\
\text { Chhattisgarh, } \\
\text { India }\end{array}$ & $\begin{array}{l}\text { Retrospec- } \\
\text { tive/Curative }\end{array}$ & 20/20 (0\%) & $\begin{array}{c}\text { SCC: } 50 \% \text {, } \\
\text { SbCC: } 40 \% \\
\text { BCC: } 10 \% \\
\text { T2: } 90 \% \\
\text { T3: } 10 \%\end{array}$ & $\begin{array}{c}\text { Interstitial } \\
\text { HDR }\end{array}$ & No & $\begin{array}{c}39 / 6 \\
\text { (curative) }\end{array}$ & 6 days \\
\hline $\begin{array}{l}\text { Krengli } \\
\text { et al. [19] }\end{array}$ & $\begin{array}{l}\text { University } \\
\text { Hospital } \\
\text { Maggiore } \\
\text { della Carità, } \\
\text { Novara, Italy }\end{array}$ & $\begin{array}{l}\text { Retrospec- } \\
\text { tive/Curative } \\
\text { or postoper- } \\
\text { ative }\end{array}$ & $60 / 60(15 \%)$ & $\begin{array}{c}\text { BCC: } 86.7 \% \text {, } \\
\text { SCC: } 11.7 \% \\
\text { MCC: } 1.6 \% \\
\text { T } \leq 3.5 \mathrm{~cm} \\
\text { Positive or } \\
\text { close surgical } \\
\text { margins } \\
\text { (<1 mm) }\end{array}$ & $\begin{array}{l}\text { Interstitial } \\
\text { LDR } \\
\text { Dose rate: } \\
\text { 50-60 cGy/h }\end{array}$ & No & $\begin{array}{l}\text { Median: } \\
65 / 1 \\
\text { (curative) } \\
\text { Median: } \\
57 / 1 \\
\text { (postopera- } \\
\text { tive) }\end{array}$ & $\begin{array}{l}\text { 3-7 days } \\
\text { (median: } \\
5 \text { days) }\end{array}$ \\
\hline $\begin{array}{l}\text { Laskar } \\
\text { et al. [20] }\end{array}$ & $\begin{array}{l}\text { Tata Memo- } \\
\text { rial Hospital, } \\
\text { Mumbai, } \\
\text { India }\end{array}$ & $\begin{array}{l}\text { Retrospec- } \\
\text { tive/Post- } \\
\text { operative }\end{array}$ & 8/8 (100\%) & $\begin{array}{c}\text { SbCC: } 50 \% \text {, } \\
\text { SCC: } 37.5 \% \\
\text { BCC: } 12.5 \% \text {, } \\
\text { PNI: } 12.5 \% \\
\text { Close margin: } \\
37.5 \%\end{array}$ & $\begin{array}{c}\text { Interstitial } \\
\text { HDR }\end{array}$ & Yes & $\begin{array}{l}\text { 21-35/7-10 } \\
\text { twice daily } \\
\text { (postopera- } \\
\text { tive) }\end{array}$ & 5 days \\
\hline $\begin{array}{l}\text { Mareco } \\
\text { et al. [21] }\end{array}$ & $\begin{array}{c}\text { Department } \\
\text { of Radiother- } \\
\text { apy Hospital } \\
\text { de Santa Ma- } \\
\text { ria, Lisbon, } \\
\text { Portugal }\end{array}$ & $\begin{array}{l}\text { Retrospec- } \\
\text { tive/Post- } \\
\text { operative or } \\
\text { curative or } \\
\text { salvage after } \\
\text { surgery }\end{array}$ & 17/17 (88.2\%) & $\begin{array}{c}\text { BCC: } 96 \% \text {, } \\
\text { SCC: } 6 \% \\
\text { CT1N0, cT2aNO } \\
\text { Positive mar- } \\
\text { gins: } 64.7 \% \\
\text { Close margins: } \\
11.7 \%\end{array}$ & $\begin{array}{c}\text { Interstitial } \\
\text { HDR }\end{array}$ & Yes & $\begin{array}{l}\text { Median: } \\
42.75 / 10 \\
\text { twice daily }\end{array}$ & 7 days \\
\hline
\end{tabular}

SCC - squamous cell carcinoma, BCC - basal cell carcinoma, SbCC - sebaceous cell carcinoma, HDR - high-dose-rate, LDR - low-dose-rate, MCC - Merkel cell carcinoma, $P N I$ - perineural invasion

${ }^{*}$ After curettage

treated with curettage and BT. The mean tumor size was $1.3 \mathrm{~cm}$ (range 1-2 cm). The delivered dose was $40 \mathrm{~Gy}$ with a mean dose rate $73 \mathrm{cGy} / \mathrm{h}$. The reported local control rate was $91.6 \%$ [14]. In the HDR group, two institution were in India $[15,20]$ and one in Portugal [21]. In India, the most common eyelid tumors are SCC and SbCC, which are considered to be more aggressive [22]. Forty five NMSC of eyelid were included and treated with different total dose and fractionation $[15,20,21]$. Azad et al. reported the results of 20 patients with different histotype (50\% SCC, $40 \%$ SbCC and 10\% BCC). Total delivered dose was 39 Gy in 6 fraction in all patients. Overall, 5-year local control rate was $75.6 \%$ (SCC: $90 \%$; SbCC: $57.1 \%$; BCC: $50 \%$ ) [15]. Laskar et al. reported the results of 8 patients with eyelid cancer treated with postoperative BT. The median tumor size was $11 \mathrm{~mm}$ but 3 patients were T4. Delivered dose 
Table 2. Summary of outcome of 5 studies included in our review

\begin{tabular}{|c|c|c|c|c|c|}
\hline $\begin{array}{l}\text { Authors } \\
\text { (reference) }\end{array}$ & $\begin{array}{l}\text { Follow up } \\
\text { (months) }\end{array}$ & LC & Acute toxicity & Late toxicity & $\begin{array}{l}\text { Functional } \\
\text { and cosmetic } \\
\text { outcome }\end{array}$ \\
\hline $\begin{array}{l}\text { Daly } \\
\text { et al. [13] }\end{array}$ & $24-72$ & $\begin{array}{l}96.4 \% \\
\text { (crude) }\end{array}$ & $\begin{array}{l}\text { Edematous reaction: } 29.6 \% \\
\text { Conjunctival erythema: } 12 \%\end{array}$ & $\begin{array}{c}\text { Epilation: } 100 \% \\
\text { Pigmentation: } 14.5 \% \\
\text { Impairment of the eyelid fissure: } 5.5 \% \\
\text { Stenosis of lacrimal duct: } 9.5 \% \\
\text { Eversion of the lower lid: } 4.4 \% \\
\text { Small ulcer of the cornea: } 0.6 \%\end{array}$ & NR \\
\hline $\begin{array}{l}\text { Conill } \\
\text { et al. [14] }\end{array}$ & Mean: 43 & $\begin{array}{l}91.6 \% \\
\text { (crude) }\end{array}$ & $\begin{array}{c}\text { G1 Edematous reaction: } 100 \% \\
\text { G1 Skin erythema: } 100 \% \\
\text { G1 Conjunctival erythema: } \\
100 \%\end{array}$ & G1-2 Epilation: 100\% & Good: $100 \%$ \\
\hline $\begin{array}{l}\text { Azad } \\
\text { et al. [15] }\end{array}$ & Median: 39.5 & $\begin{array}{l}\text { 5-year: } \\
75.6 \%\end{array}$ & $\begin{array}{l}\text { Erythema and mild lid ede- } \\
\text { ma: } 90 \% \\
\text { Conjunctival congestion and } \\
\text { chemosis: } 55 \%\end{array}$ & $\begin{array}{l}\text { Keratitis: } 5 \% \\
\text { Epiphora: } 5 \% \\
\text { Lid fibrosis: } 15 \% \\
\text { Depigmentation: } 10 \% \\
\text { Epilation: } 70 \% \\
\end{array}$ & $\begin{array}{l}\text { Good and ac- } \\
\text { ceptable: } 100 \%\end{array}$ \\
\hline $\begin{array}{l}\text { Krengli } \\
\text { et al. [19] }\end{array}$ & Mean: 92 & $\begin{array}{l}96.7 \% \\
\text { (crude) }\end{array}$ & $\begin{array}{l}\text { G2-G3 Conjunctivitis: } 80 \% \\
\text { G1 Keratitis: } 21.7 \%\end{array}$ & $\begin{array}{c}\text { Stenosis of lacrimal duct: } 6.7 \% \\
\text { G1 Epiphora: } 5 \% \\
\text { Ectropion: } 5 \% \\
\text { Unilateral cataract: } 3.3 \%\end{array}$ & $\begin{array}{l}\text { Optimal: } 68.3 \% \\
\text { Satisfactory: } \\
23.3 \% \\
\text { Unsatisfactory: } \\
\quad 8.3 \% \\
\end{array}$ \\
\hline $\begin{array}{l}\text { Laskar } \\
\text { et al. [20] }\end{array}$ & Median: 35 & $\begin{array}{l}100 \% \\
\text { (crude) }\end{array}$ & $\begin{array}{l}\text { G1 Erythema: } 75 \% \\
\text { G1 Epiphora: } 25 \%\end{array}$ & $\begin{array}{l}\text { G1 Pigmentation: } 14.2 \% \\
\text { G1 Ectropion: } 14.2 \%\end{array}$ & $\begin{array}{l}\text { Excellent/very } \\
\text { good: } 100 \%^{*}\end{array}$ \\
\hline $\begin{array}{l}\text { Mareco } \\
\text { et al. [21] }\end{array}$ & Median: 40 & $\begin{array}{l}94.1 \% \\
\text { (crude) }\end{array}$ & $\begin{array}{l}\text { G1 Radiodermatitis: } 52 \% \\
\text { G2 Radiodermatitis: } 12 \% \\
\text { G3 Radiodermatitis: } 12 \% \\
\text { G1 Conjunctivitis: } 42 \% \\
\text { Hematoma: } 46 \%\end{array}$ & $\begin{array}{c}\text { G1-2 Keratoconjuctivitis secca: } 46 \% \\
\text { G1-2 Conjuctivitis: } 42 \% \\
\text { G1-2 Epilation: } 65 \% \\
\text { G1-2 Skin atrofy: } 36 \% \\
\text { G1-2 Eyelid malocclusion: } 46 \% \\
\text { G1-2 Impairment of the eye aperture: } 12 \% \\
\text { G1-2 Edema: } 18 \% \\
\text { G1-2 Fibrosis: } 18 \% \\
\text { G1-2 Pruritus: } 46 \% \\
\text { G1-2 Burn pain: } 36 \% \\
\text { G1-2 Pigmentation changes: } 47 \% \\
\text { G1-2 Hyperlacrimation: } 18 \% \\
\text { G1-2 Entropion: } 23 \%\end{array}$ & $\begin{array}{c}\text { Excellent: } 29 \% \\
\text { Good: } 41 \% \\
\text { Satisfactory: } \\
12 \% \\
\text { Not available: } \\
18 \%\end{array}$ \\
\hline
\end{tabular}

ranged from $21 \mathrm{~Gy}$ in 7 fractions to $35 \mathrm{~Gy}$ in 10 fractions (twice daily fractionation with 6-8 hours gap). No local recurrences were reported but two patients had nodal recurrence 6 months after interstitial BT [20].

The last study reported the results of 17 patients, where BT was delivered in different setting (curative: 2 patients, postoperative: 12 patients, salvage after surgery: 3 patients). The median total dose was 42.75 Gy (range: $32-50$ Gy) with a median of 10 fractions (range: 9-11 fractions), twice daily fractionation with 6 hours gap. The median follow up was 40 months with $94.1 \%$ local control [21].

\section{Acute-late toxicity and functional cosmetic outcome}

All series reported low rates of treatment-related toxicity. Four studies did not use eye shield [13, 14, 15, 19]. Two studies used a custom made shield [20, 21]. One study used a shield conformer from dental prosthesis material [20] and the other one a lead shielding covered with paraffin to prevent additional dose to healthy tissues of the eye [21]. Edematous reaction, lid erythema, and conjunctivitis were the most common acute toxicity reported, ranging from $12 \%$ to $100 \%$ of cases $[14,15,19,20,21]$. Radiodermatitis G1, G2, and G3 were reported in one study (52\%, $12 \%$, and $12 \%$, respectively) [21]. Also G1 keratitis were reported in $21.7 \%$ of cases and some patients required local therapy or systemic therapy [19]. One study reported hematoma after needle insertion in $46 \%$ of patients but was resolved without therapy [21]. In another study, 6-8 weeks after the implant, persistent edematous (29.6\%) and conjunctival reaction (12\%) were observed [13].

Epilation of the treated area was the most common late toxicity reported ranging $65-100 \%[13,14,15,21]$. 
Pigmentation was reported in four studies ranging from $10 \%$ to $47 \%[13,15,20,21]$ and lid fibrosis in two studies ranging from $15 \%$ to $18 \%[15,21]$. Other late toxicities reported less frequently were: lacrimal duct stenosis (range $6.7-9.5 \%)[13,19]$, eyelid fissure impairment $(5.5-12 \%)$ [13, $21]$, epiphora (range 5-25\%) [13, 19, 20], unilateral cataract (3.3\%) [19], ectropion (range 4.4-14.2\%) [13, 20], entropion $(23 \%)$, conjunctivitis $(42 \%)$, keratoconjuctivitis secca $(46 \%)$, eyelid malocclusion $(46 \%)$, edema $(18 \%)$, fibrosis $(18 \%)$, pruritus $(46 \%)$, hyperlacrimation $(18 \%)$ [21], and small corneal ulcer $(0.6 \%)$ [13]. Recurrent lesions and larger volumes were associated with worse outcomes $[13,21]$.

No validated cosmesis scale after BT in eyelid cancer were used in these studies. Functional and cosmetic outcome were reported according to the physicians [19] or patients judgement [21], Cosmesis After Interstitial Brachytherapy (CAIB) scale [20] or not specified [14, 15]. Only in one study was cosmesis graded and documented using a 6 domain objective scoring criteria (depigmentation of skin, eyelid dysfunction like ectropion or entropion, dry eye, keratitis, cataract, and glaucoma) [20]. Functional and cosmetic outcomes were reported in 5 studies and graded as optimal to good/excellent in $68.3-100 \%$, respectively $[14,15,19,20,21]$.

\section{Discussion}

\section{Treatment of eyelid cancer}

Surgery is considered the gold standard treatment for eyelid tumors. The aims of treatment is definitive tumor control with functional preservation of anatomical structures $[6,7,8]$. Radiotherapy is an effective alternative in patients where surgery might be associated with functional or cosmetic deficits or in patients unfit because of comorbidities.

The only randomized trial comparing radiotherapy versus surgery in patients with BCC of the face was published by Avril et al. in 1997. Basal cell carcinoma of eyelid represented $19 \%$ of surgery group and $20 \%$ of radiotherapy group. Three radiation techniques were used. Interstitial BT was performed with ${ }^{192}$ Ir-wires afterloaded with a dose of 65-70 Gy delivered over a period of 5-7 days. Superficial contact therapy $(50 \mathrm{kV})$ was delivered in two sessions, each delivering 18-20 Gy with a 2-week interval. Basal cell carcinoma of less than $2 \mathrm{~cm}$ in the largest diameter were treated with this technique. Conventional radiotherapy $(85-250 \mathrm{kV})$ was delivered with $60 \mathrm{~Gy}$ total dose in treatment fractions ranging from 2 to $4 \mathrm{~Gy}$. In the radiotherapy group, 55\% were treated with interstitial BT, 33\% with contact therapy, and $12 \%$ with conventional radiotherapy. The 4-year actuarial failure rate was $7.5 \%$ in the radiotherapy group compared with $0.7 \%$ in the surgery group. The cosmetic results were significantly better after surgery than after radiotherapy. However, no analysis of outcomes according the treatment site or radiotherapy technique was performed [23].

Only few studies are available in literature regarding the use of BT in eyelid NMSC. In all studies, the patients population was very heterogeneous in terms of histology, treatment aim (curative or adjuvant), dose rate (LDR and
HDR), total dose, and follow up time $[13,14,15,19,20$, 21]. The level of evidence was low ( 3 in all studies according to SIGN criteria).

\section{Comparisons between analyzed studies}

\section{Local control}

It is difficult to make a comparison because in $5 / 6$ studies, LC was reported in terms of crude rate. Therefore, these results are probably influenced by the follow-up length $[13,14,19,20,21]$. The only study reporting actuarial LC is the one of Azad et al. [15] and this difference may explain the lower results [15]. Among the authors reporting the crude rate, Conill et al. [14] had slightly lower results (LC: $91.6 \%$ ) compared to the others (94.1-100\%) $[13,20,21]$. This might indicate that the use of curettage (performed by Conill) did not produces benefits in terms of disease control [14]. It should also be noted that Conill, among the studies based on $\operatorname{LDR}[13,14,19]$, is the one with the lowest total delivered dose [14].

\section{Acute toxicity}

Only 4 studies reported the used acute toxicity score $[14,19,20]$. Edema was reported in three studies $[13,14,15]$ with variable incidence $(29.6-100 \%)$ [13, 14]. Conjunctival erythema or conjunctivitis was reported in 3 studies $[13,14,19]$ and in the other two studies the site of erythema was not specified (skin?, conjunctiva?) [15, 20]. Daly et al. reported the lowest incidence of edema and conjunctival erythema ( $29.6 \%$ and $12 \%$, respectively) [13]. It is not clear whether it is a real difference or if the authors [13] reported only the most obvious cases. Other toxicities were reported in individual studies, $21.7 \%$ of keratites [19] and $29 \%$ of epiphora [20]. Therefore, due to inhomogeneous and non-standardized reporting of acute toxicity, the identification of potential predictors of short term side-effects between the different studies results was difficult.

\section{Late toxicity}

Only 3 studies reported the used late toxicity score [14, $20,21]$. Epilation was reported in 4 studies $[13,14,15,21]$ ranging from 65 to $100 \%$. The lowest value was reported by Mareco et al. where a correlation between $\mathrm{V}_{100}$ (volume of the tissue that receives $100 \%$ of the prescription dose) and $V_{150}$ (volume of the tissue that receives $150 \%$ of the prescription dose), and epilation was observed. $\mathrm{V}_{100}$ $\geq 2 \mathrm{~cm}^{3}$ and $V_{150} \geq 1 \mathrm{~cm}^{3}$ were associated with higher epilation frequency [21]. It is difficult to compare with other studies because this data was not reported.

Epiphora was reported in 2 studies with the same incidence $(5 \%)[15,19]$ as well as lacrimal duct stenosis, which was reported in 2 studies with a similar incidence $(6.7-9.5 \%)[13,19]$. Pigmentation changes was reported in 4 studies [13, 15, 20, 21] (incidence 10-47\%) and impairment of eyelid fissure in 2 studies (incidence 5.5-12\%) [13, 21]. The highest incidence was reported by Mareco et al., again $\mathrm{V}_{150} \geq 1 \mathrm{~cm}^{3}$ seemed to be correlated with the frequency of late toxicities [21]. 
Ectropion was reported in 2 studies (5-14.2\%) [19, 20] and 1 study reported the eversion of the lower lid in $4.4 \%$ of patients [13].

Other late toxicities reported in individual studies were unilateral cataract, entropion, conjunctivitis, keratoconjunctivitis sicca, eyelid malocclusion, hyperlacrimation, and small corneal ulcer with incidences of 3.3\% [19], 23\% [21], 42\% [21], 46\% [21], 46\% [21], 18\% [21], and $0.6 \%$ [13], respectively. Therefore, even for late toxicity, it is difficult to identify predicting factors.

\section{Cosmetic outcome}

Cosmetic outcome was reported in 5 studies [14, 15, $19,20,21]$. Good-optimal scores ranged from $68.3 \%$ to $100 \%$ of cases. The only study reporting unsatisfactory results is the one of Krengli et al. (8.3\%) [19]. It should be noted that in this trial the prescribed dose was the highest between the analyzed trials. Recurrent lesions [13, 21] and higher volumes receiving the prescribed dose were associated with worst cosmetic outcomes [21].

\section{Conclusions}

In conclusion, evidences from studies comparing the results of BT with other treatments are lacking in literature. Furthermore, due to low evidence of the published studies it is challenging to draw any meaningful conclusions about factors correlated with tumor control and toxicity based on available data. Some scattered evidence seem to suggest that the association with curettage is not beneficial and that the use of lower doses is associated with a higher incidence of local failure. Moreover, the use of higher doses and higher volumes receiving the prescribed dose seems to be associated with a worse cosmetic outcome while prolonged treatment would produce less late effects at least from the point of view of epilation. Finally, we can conclude that BT in small tumor size $(\mathrm{T} \leq 3.5 \mathrm{~cm})$ or in postoperative treatment of high risk patients (positive or close margin, perineural invasion) resulted in high local control rates (median: 95.2\%) with acceptable-good functional cosmetic outcome (median: $100 \%)$, mainly based on retrospective studies $[13,14,15$, $19,20,21]$. Therefore, prospective controlled trials evaluating not only local control but also functional cosmetic outcome with validated scale are justified.

\section{Disclosure}

Authors report no conflict of interest.

\section{References}

1. Petsuksiri J, Frank SJ, Garden AS et al. Outcomes after radiotherapy for squamous cell carcinoma of the eyelid. Cancer 2008; 112: 111-118.

2. Cook BE Jr, Bartley GB. Treatment options and future prospects for the management of 166 eyelid malignancies: an evidence-based update. Ophthalmology 2001; 108: 2088-2098.

3. Vu A, Laub D Jr. Metastatic Basal cell carcinoma: a case report and review of the literature. Eplasty 2011; 11: 1-7.

4. Rowe DE, Carroll RJ, Day CL Jr. Prognostic factors for local recurrence, metastasis, and survival rates in squamous cell carcinoma of the skin, ear, and lip. Implications for treatment modality selection. J Am Acad Dermatol 1992; 26: 976-990.

5. Murchinson AP, Walrath JD, Washington CV. Non-surgical treatments of primary, non-melanoma eyelid malignancies: a review. Clin Experiment Ophthalmol 2011; 39: 65-83.

6. Mohs FE. Micrographic surgery for the microscopically controlled excision of eyelid cancers. Arch Ophthalmol 1986; 104: 901-909.

7. Mosterd K, Krekels GA, Nieman FH et al. Surgical excision versus Mohs' micrographic surgery for primary and recurrent basal-cell carcinoma of the face: a prospective randomized controlled trial with 5-years' follow-up. Lancet Oncol 2008; 9: 1149-1156.

8. Malhotra R, Huilgol SC, Huynh NT et al. The Australian Mohs database: periocular squamous cell carcinoma. Ophthalmology 2004; 111: 617-623.

9. http://www.ncbi.nlm.nih.gov/pubmed, accessed on October 13, 2015.

10. http:/ / www.scopus.com/, accessed on October 13, 2015.

11. http:/ / www.cochranelibrary.com/, accessed on October 13, 2015.

12. http:/ / www.sign.ac.uk/, accessed on January 8, 2015.

13. Daly NJ, de Lafontan B, Combes PF. Results of the treatment of 165 lid carcinomas by iridium wire implant. Int J Radiat Oncol Biol Phys 1984; 10: 455-459.

14. Conill C, Sánchez-Reyes A, Molla M et al. Brachytherapy with 192Ir as treatment of carcinoma of the tarsal structure of the eyelid. Int J Radiat Oncol Biol Phys 2004; 59: 1326-1329.

15. Azad S, Choudhary V. Treatment results of high dose rate interstitial brachytherapy in carcinoma of eye lid. J Cancer Res Ther 2011; 7: 157-161.

16. Shields JA, Demirci H, Marr BP et al. Sebaceous carcinoma of the eyelids: personal experience with 60 cases. Ophthalmology 2003; 111: 2151-2157.

17. Rio E, Bardet E, Ferron $C$ et al. Interstitial brachytherapy of periorificial skin carcinomas of the face: a retrospective study of 97 cases. Int J Radiat Oncol Biol Phys 2005; 63: 753-757.

18. Ducassou A, David I, Filleron T et al. Retrospective analysis of local control and cosmetic outcome of 147 periorificial carcinomas of the face treated with low-dose rate interstitial brachytherapy. Int J Radiat Oncol Biol Phys 2011; 81: 726-731.

19. Krengli M, Masini L, Comoli AM et al. Interstitial brachytherapy for eyelid carcinoma. Outcome analysis in 60 patients. Strahlenther Onkol 2014; 190: 245-249.

20. Laskar SG, Basu T, Chaudhary S et al. Postoperative interstitial brachytherapy in eyelid cancer: long term results and assessment of Cosmesis After Interstitial Brachytherapy scale. J Contemp Brachytherapy 2014; 6: 350-355.

21. Mareco V, Bujor L, Abrunhosa-Branquinho AN et al. Interstitial high-dose-rate brachytherapy in eyelid cancer. Brachytherapy 2015; 14: 554-564.

22. Dailey JR, Kennedy RH, Flaharty PM et al. Squamous cell carcinoma of the eyelid. Ophthal Plast Reconstr Surg 1994; 10: 153-159.

23. Avril MF, Auperin A, Margulis A et al. Basal cell carcinoma at the face: surgery or radiotherapy? Results of a randomized study. Br J Cancer 1997; 76: 100-106. 